\title{
Synthesis and structure optimization of double (fluorescent and spin) sensor molecules
}

\author{
Tamás Kálai, ${ }^{a}$ Olga H. Hankovszky, ${ }^{a}$ Éva Hideg, ${ }^{b}$ József Jekő, $^{c}$ and Kálmán Hideg ${ }^{\text {a* }}$ \\ ${ }^{a}$ Institute of Organic and Medicinal Chemistry, University of Pécs, H-7643 Pécs, P. O. Box 99, \\ Hungary \\ ${ }^{b}$ Institute of Plant Biology, Biological Research Center, Hungarian Academy of Sciences, $H$ - \\ 7601 Szeged, P. O. Box 521, Hungary \\ ${ }^{c}$ ICN Hungary Ltd., H-4440, Tiszavasvári, P. O. Box 1, Hungary \\ E-mail: khideg@main.pote.hu
}

Dedicated to Professor Douglas Lloyd on the occasion of his $80^{\text {th }}$ birthday

\begin{abstract}
Synthesis and fluorescence properties of stable nitroxide free radicals (10a, 11a, 12a, 14a, 20a, 21a) and their amine $(\mathbf{1 0 b}, \mathbf{1 1 b}, \mathbf{1 2 b}, \mathbf{1 4 b}, \mathbf{2 0 b}, \mathbf{2 1 b})$ precursors covalently linked to dansyl or 3and 4-aminophthalimide are reported. The best intramolecular quenching is achieved when the fluorophore and the nitroxide are in the closest possible position
\end{abstract}

Keywords: Fluorescence, sensor molecules, nitroxide, free radicals, aminophthalimide

\section{Introduction}

Fluorescence and spin double sensors are important probe molecules for detecting free radicals both in condensed- ${ }^{1-4}$ and gas-phases ${ }^{5}$. Their sensing ability is based on the energy transfer from a donor moiety (fluorophore) to an acceptor moiety (nitroxide) which results in quenched fluorescence. The possible quenching mechanisms of these compounds are well discussed. ${ }^{6-8}$ Absence of acceptor in the diamagnetic derivatives of these probe molecules, exhibit strong fluorescence. Utilizing these probes, Reactive Oxygen Species (ROS) production can be followed on the basis of either fluorescence quenching or the EPR detectable appearance of nitroxide. In case of biological application other requirements arise: to avoid the overlapping with background emission of intrinsic fluorophores, water solubility and permeability through membranes. Applications also require a large difference between the fluorescence emission of the amine and the corresponding nitroxide, in order to assure sensitive detection of ROS. Recently we have developed a sensor molecule for biological application, called DanePy ${ }^{1} \mathbf{1 b}$, which is readily oxidized by ROS to nitroxide 1a (Scheme 1). 


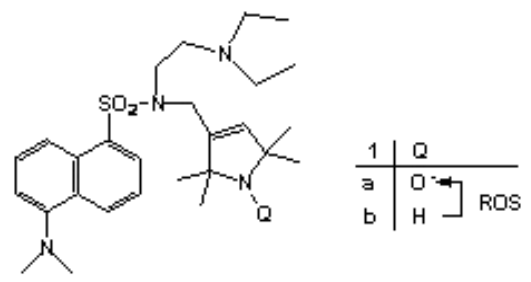

\section{Scheme 1}

Similar oxidation reaction was also observed earlier in vivo. ${ }^{9}$ The diethylaminoethyl side-chain in DanePy 1b ensures water solubility and penetration into chloroplasts. ${ }^{10}$ In this paper we discuss the role of spacer group on quenching of fluorescence as well as extension of this idea to other aminophthalimide fluorophores to obtain more sensitive double sensors.

\section{Results and Discussion}

In our previous studies we experienced the advantage of a protonable amino group in spacer to increase of solubility in aqueous media. We achieved this by inserting of piperazine, or 1-(2aminoethyl)piperazine as spacer group between nitroxide and fluorophore in double sensors. This could be accomplished by alkylating piperazine with allylic bromide ${ }^{11} 2$ in $\mathrm{CHCl}_{3}$ in the presence of $\mathrm{K}_{2} \mathrm{CO}_{3}$ to give mixture of the monoalkylated compound $\mathbf{3}$ and the dialkylated compound 4. The $N$-[2-(1-piperazidinyl)ethyl]phthalimide $\mathbf{5}^{12}$ could be alkylated on the secondary nitrogen atom under the above conditions to yield compound $\mathbf{6}$. Treatment of phthalimide derivative 6 with methylamine ${ }^{13}$ in ethanol allowed the mild deprotection of the terminal amino group to give compound 7 (Scheme 2).

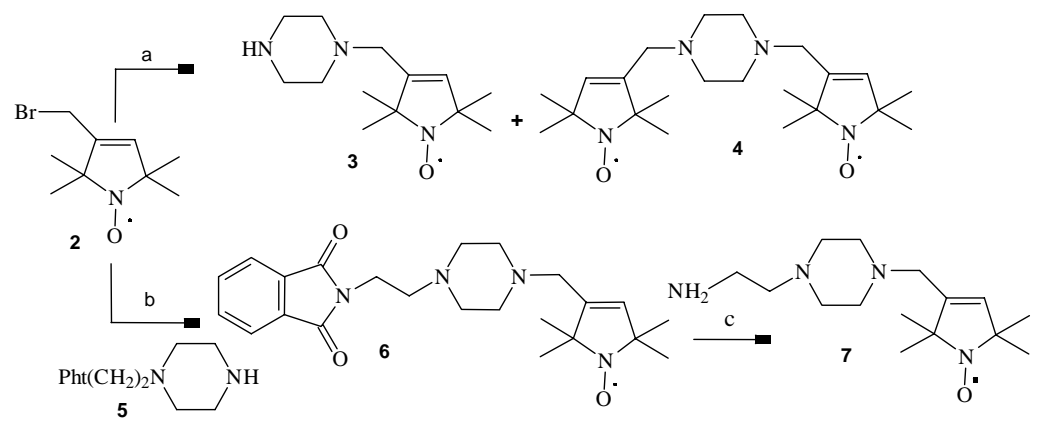

\section{Scheme 2}

Reagents and conditions: (a) piperazine (3 eq.), $\mathrm{K}_{2} \mathrm{CO}_{3}$ (1 eq.), $\mathrm{CHCl}_{3}$, reflux, 1 h, 3 (40 \%), 4 (37 \%); (b) 5 (1 eq.), $\mathrm{K}_{2} \mathrm{CO}_{3}$ (1 eq.), $\mathrm{CHCl}_{3}$, reflux, 2 h, (74 \%); (c) $\mathrm{CH}_{3} \mathrm{NH}_{2}$, EtOH, r.t. 12 h, (33\%). 
Amines 3 and 7 as well as allylic amine $\mathbf{8}^{14}$ were treated with 5-dimethylamino-1naphtalenesulfonyl chloride 9 in $\mathrm{CH}_{2} \mathrm{Cl}_{2}$ in the presence of triethylamine to get the paramagnetic dansyl derivatives 10a, 11a and 12a. The paramagnetic compounds were reduced to sterically hindered amines 10b, 11b and $\mathbf{1 2 b}$ by Fe powder in glacial acetic acid ${ }^{15}$ (Scheme 3).
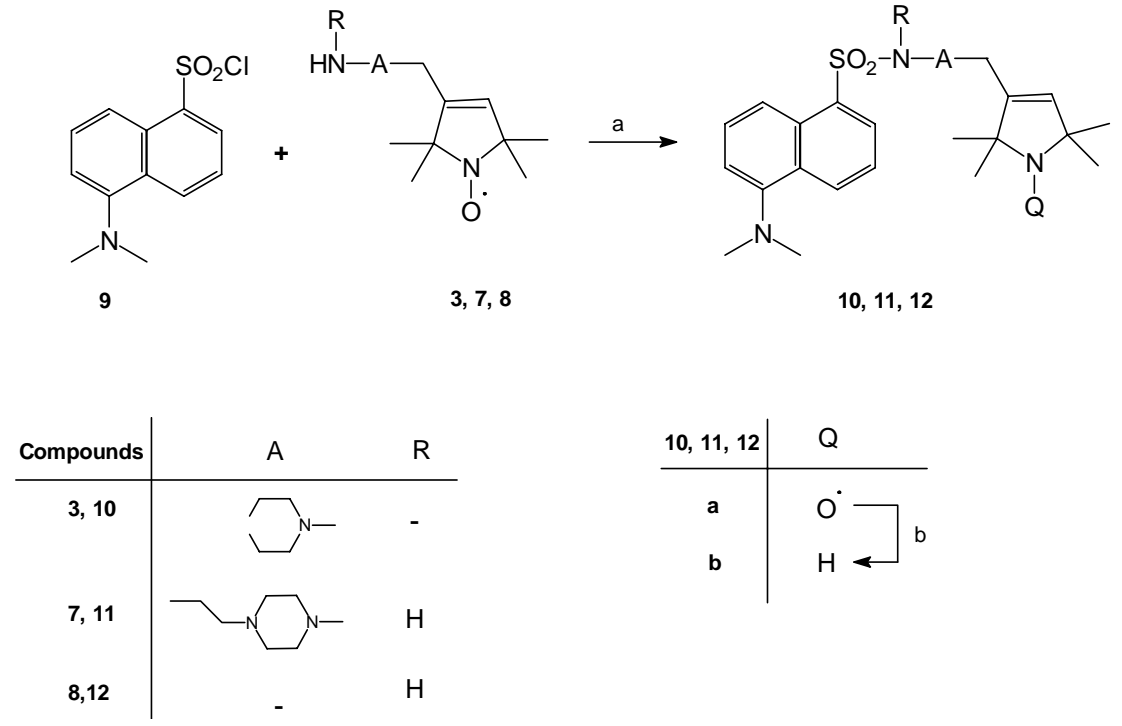

\section{Scheme 3}

Reagents and conditions: (a) 8 (1.0 eq.) $\mathrm{CH}_{2} \mathrm{Cl}_{2}, \mathrm{Et}_{3} \mathrm{~N}$ (1.1 eq.), r.t., 4 h, (45-58 \%); (b) Fe (5 eq.), $\mathrm{AcOH}, 80{ }^{\circ} \mathrm{C}, 30 \mathrm{~min}$, then $\mathrm{K}_{2} \mathrm{CO}_{3}$, (32-48\%).

However, comparing the ratios of fluorescence emission maxima of amines $\mathbf{1 0 - 1 2 b}$ versus nitroxides 10-12a in case of compound 10, 11 became less advantageous than 12b/12a ratio (Table 1).

Table 1. Fluoresence emission data of compounds 1, 10, 11, 12, 14, 20, 21 in K-phosphate buffer (50mM, pH 7.2) containing $5 \%$ or $20 \%{ }^{*} \mathrm{EtOH}$.

\begin{tabular}{|c|c|c|c|}
\hline Compound & $\begin{array}{l}\text { a (NO) emission } \\
\max (\mathrm{nm})\end{array}$ & $\begin{array}{l}\text { b (NH) emission max } \\
(\mathrm{nm})\end{array}$ & $\begin{array}{l}\text { Peak intensity } \\
\text { ratio (b/a) }\end{array}$ \\
\hline 1 & 530 & 551 & 5.56 \\
\hline 10 & 560 & 556 & 1.57 \\
\hline 11 & 545 & 550 & 1.10 \\
\hline 12 & 540 & 550 & 6.39 \\
\hline 14 & 519 & 523 & 28.13 \\
\hline 20 & 546 & 503 & 25.00 \\
\hline $21^{*}$ & 532 & 528 & 9.11 \\
\hline
\end{tabular}


The introduction of a long spacer between the donor and the acceptor moieties decreased the rate of quenching of fluorescence, because the rate of Coulombic energy transfer inversely proportional to the sixth power of distance between donor and acceptor. While electron transfer or electron exchange rate decrease exponentially with increasing donor-acceptor distance. ${ }^{16}$ To get better double sensor molecules, i. e. to achieve better ratio of emission maxima of amine versus nitroxide we investigated compound $13 .{ }^{17}$ The sodium salt of $\mathbf{1 3}$ was alkylated in dimethylformamide/THF mixture with freshly released 2-(diethylamino)ethyl chloride to give compound 14a, which was then reduced to 14b with Fe powder in $\mathrm{AcOH}$ (Scheme 4). Fluorescence emission maxima ratio of compounds $14 \mathbf{b}$ and $14 \mathbf{a}$ were the highest among the investigated dansyl derivatives (Table 1).

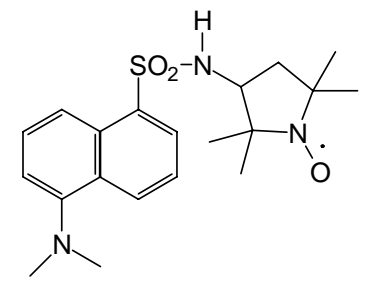

13

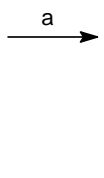

\section{Scheme 4}

Reagents and conditions: (a) $\mathrm{NaH}$ (2.0 eq.), dry THF, $0{ }^{\circ} \mathrm{C}, 15 \mathrm{~min}$. then add benzene extract of aq. solution of 2-(diethylamino)ethyl chloride hydrochloride (5.0 eq.), $\mathrm{K}_{2} \mathrm{CO}_{3}$ (5.0 eq.), then add dry DMF, $0 \rightarrow 65{ }^{\circ} \mathrm{C}$, $3 \mathrm{~h}$ (34 \%); (b) Fe (5 eq. ), $\mathrm{AcOH}, 80^{\circ} \mathrm{C}, 30$ min, then $\mathrm{K}_{2} \mathrm{CO}_{3}$, (28 \%).

This idea can be extended to other donor-acceptor pairs as we demonstrate in the case of 3- and 4-aminophthalimide as donor and 1-oxyl-2,2,6,6-tetramethyl piperidine as acceptor. We chose 3and 4-aminophthalimides because beyond their fluorescence properties they exhibited the ability of recognizing CG Watson-Crick base pair, as reported very recently. ${ }^{18}$ Reaction of 3nitrophthalic anhydride 15 or 4-nitrophthalic anhydride 16 with 4-amino-1-oxyl-2,2,6,6tetramethyl piperidine 17 in $\mathrm{CHCl}_{3}$ followed by cyclocondensation of amides (not shown) in toluene in the presence of $\mathrm{Et}_{3} \mathrm{~N}$ gave paramagnetic 3-nitrophthalimide 18 and 4-nitrophthalimide 19 derivatives. Selective reduction of nitro compounds 18, 19 with ammonium formate in $\mathrm{MeOH}$ in the presence of $\mathrm{Pd} / \mathrm{C}^{19}$ yielded compounds 20a and 21a, respectively, although re-oxidation of hydroxylamines with $\mathrm{PbO}_{2} / \mathrm{O}_{2}$ was required. Treatment of paramagnetic 3- and 4nitrophthalimide derivatives with Fe powder in $\mathrm{AcOH}$ resulted in simultaneous reduction of both nitro and nitroxide groups to the corresponding amines in order to give compounds $\mathbf{2 0 b}$ and $\mathbf{2 1 b}$. In the case of compounds $20 \mathbf{b}$ and $\mathbf{2 0 a}$ we also got very good amine versus nitroxide fluorescence intensity ratio (Scheme 5). 


\section{Scheme 5}

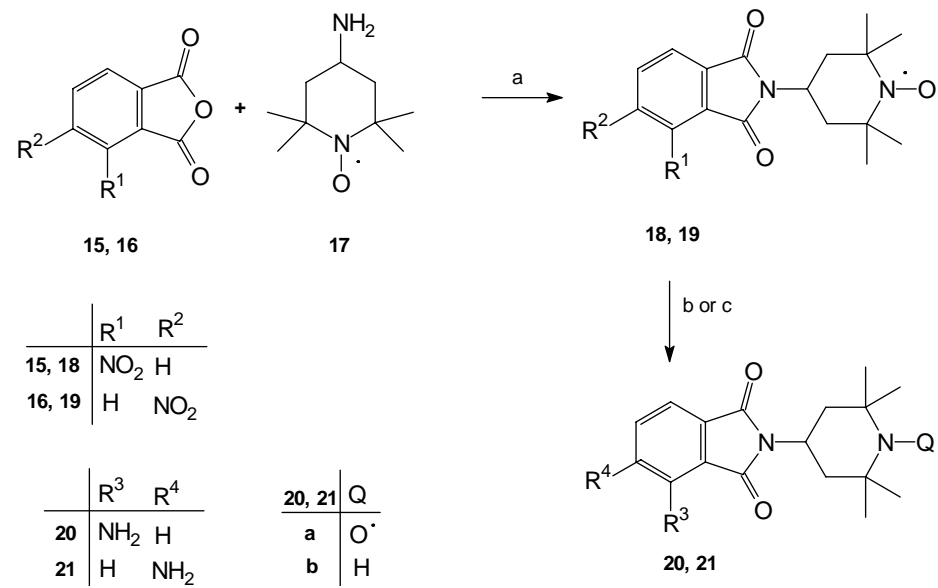

Reagents and conditions: (a) 15 or 16 (1 eq.) and 17 (1 eq.), $\mathrm{CHCl}_{3}$, r.t., $1 \mathrm{~h}$, then evaporate, toluene, $\mathrm{Et}_{3} \mathrm{~N}$ (3 eq), $8 \mathrm{~h}, 110{ }^{\circ} \mathrm{C}$ (30-44 \%); (b) $\mathrm{HCO}_{2} \mathrm{NH}_{4}$ (6 eq.), $\mathrm{Pd} / \mathrm{C}$ (cat.), $\mathrm{MeOH}, 40{ }^{\circ} \mathrm{C}, 2$ h, then $\mathrm{PbO}_{2}$ (cat.)/O 15 min., (28-36 \%); (c) Fe (5 eq. ), $\mathrm{AcOH}, 50{ }^{\circ} \mathrm{C}, 30 \mathrm{~min}$, then $\mathrm{K}_{2} \mathrm{CO}_{3}$, (33-51\%).

In conclusion, the best double sensor reagents among the ones we tested were those with a minimal acceptor-donor distance. However, side-chains may prove to be advantageous in further biological applications.

\section{Experimental Section}

General Procedures. Melting points were determined with Boetius micro melting point apparatus and are uncorrected. Elemental analyses (C, H, N, S) were performed on Fisons EA 1110 CHNS elemental analyser. Mass spectra were recorded on a VG TRIO-2 instrument in EI mode (70 eV, direct inlet) or with thermospray technique (TSP). Samples were analyzed in bypass mode. $10 \mu \mathrm{L}$ of the sample solution in $\mathrm{MeOH}$ was introduced via the thermospray interface. The mobile phase was $\mathrm{MeOH} / \mathrm{H}_{2} \mathrm{O}(1: 1)$ containing $0.1 \mathrm{M} \mathrm{NH}_{4} \mathrm{OAc}$. The capillary tip temperature was $230{ }^{\circ} \mathrm{C}$, the electrode voltage was $180 \mathrm{~V}$ and source temperature $210{ }^{\circ} \mathrm{C}$. The ESR spectra were obtained from $10^{-5}$ molar solution $\left(\mathrm{CHCl}_{3}\right)$, using Bruker ECS-106 spectrometer. All monoradicals exhibit three equidistant lines with $\mathrm{a}_{\mathrm{N}}=14.3-14.8 \mathrm{G}$. Fluorescence emission spectra were recorded with Quanta Master QM-1 (Photon Technology International Inc.) using $345 \mathrm{~nm}$ excitation wavelength and $1 \mathrm{~nm}$ excitation and emission slits. The fluorescence emission peak intensities were normalised by concentration. Flash column chromatography was performed on Merck Kieselgel 60 (0.040-0.063 mm). TLC was carried out on commercially prepared plates $(20 \times 20 \times 0.02 \mathrm{~cm})$ coated with Merck Kieselgel $\mathrm{GF}_{254}$. Compounds 9, 15, 16, 17 were purchased from Aldrich. Compounds $\mathbf{1},{ }^{1} \mathbf{5},{ }^{12} \mathbf{1 1}^{17}$ were prepared according to published procedures. 
Synthesis of 1-(1-oxyl-2,2,5,5-tetramethyl-2,5-dihydro-1H-pyrrol-3-ylmethyl)pipe-razine radical 3 and bis-[1,4-(1-Oxyl-2,2,5,5-tetramethyl-2,5-dihydro-1H-pyrrol-3-ylmethyl)] piperazine biradical (4). A mixture of piperazine (2.58 g, $30.0 \mathrm{mmol}), \mathrm{K}_{2} \mathrm{CO}_{3}$ (1.38 g, $10.0 \mathrm{mmol}$ ) and allylic bromide 2 (2.33 g, $10.0 \mathrm{mmol})$ in $\mathrm{CHCl}_{3}(30 \mathrm{~mL})$ was stirred and refluxed for $1 \mathrm{~h}$. After cooling the mixture was filtered, the organic phase was washed with brine $(20 \mathrm{~mL})$, dried $\left(\mathrm{MgSO}_{4}\right)$, filtered and evaporated. The residue was purified by flash chromatography (hexane/EtOAc) to give compound $4720 \mathrm{mg}$ (37\%), mp $150-154{ }^{\circ} \mathrm{C}$ as a second band (the first band is compound 2). Calc. for $\mathrm{C}_{22} \mathrm{H}_{38} \mathrm{~N}_{4} \mathrm{O}_{2} \mathrm{C} 67.66, \mathrm{H} 9.81, \mathrm{~N} 14.34$; found C 67.80, H 9.95, $\mathrm{N}$ 14.40; MS (EI) m/z: 390 (M+, 23), 375 (10), 122 (94), 41 (100). Elution with $\mathrm{CHCl}_{3} / \mathrm{Et}_{2} \mathrm{O}$ gave compound 3 952mg (40\%) as a third band, thick oil. Calc. for $\mathrm{C}_{13} \mathrm{H}_{24} \mathrm{~N}_{3} \mathrm{O} \mathrm{C}$ 65.51, $\mathrm{H} \mathrm{10.15,} \mathrm{N}$ 17.63; found: C 65.60, H 10.20, N 17.50; MS (EI) m/z: 238 (M $\left.\mathrm{M}^{+}, 12\right), 224$ (6), 138 (28), 99 (100).

Synthesis of $\mathrm{N}$-\{2-[4-(1-oxyl-2,2,5,5-tetramethyl-2,5-dihydro-1 $\mathrm{H}$-pyrrol-3-ylmethyl) piperazin-1yl]ethyl phthalimide (6). To a solution of compound 5 (2.59 g , $10.0 \mathrm{mmol})$ and $\mathrm{K}_{2} \mathrm{CO}_{3}(1.38 \mathrm{~g}$, $10.0 \mathrm{mmol})$ in $\mathrm{CHCl}_{3}(30 \mathrm{~mL})$ allylic bromide 2 (2.33 g, $\left.10.0 \mathrm{mmol}\right)$ was added and the mixture was stirred and refluxed for $2 \mathrm{~h}$. After cooling the mixture was filtered, washed with brine $(10 \mathrm{~mL})$, dried $\left(\mathrm{MgSO}_{4}\right)$, evaporated. Flash column chromatography $\left(\mathrm{CHCl}_{3} / \mathrm{Et}_{2} \mathrm{O}\right)$ afforded compound 63.04 g (74\%), mp 127-132 ${ }^{\circ} \mathrm{C}$. Calc. for $\mathrm{C}_{23} \mathrm{H}_{31} \mathrm{~N}_{4} \mathrm{O}_{3} \mathrm{C}$ 67.13, H 7.59, N 13.61; found: C 67.20, H 7.70, N 13.75 MS (TSP) m/z: $412(\mathrm{M}+\mathrm{H})^{+}$.

Synthesis of 1-Oxyl-3-[4-(2-aminoethyl)piperazin-1-ylmethyl]-2,2,5,5-tetramethyl-2,5-dihydro$1 \mathrm{H}$-pyrrole (7). To a solution of compound 6 (3.0 g, $7.30 \mathrm{mmol})$ in EtOH (10 mL) $40 \% \mathrm{MeNH}_{2}$ solution in EtOH was $(10 \mathrm{~mL})$ added and the mixture was allowed to stay at rt for $12 \mathrm{~h}$. The solvent was evaporated off, the residue was dissolved in $\mathrm{CHCl}_{3}(25 \mathrm{~mL}$ ), washed with brine, dried $\left(\mathrm{MgSO}_{4}\right)$, filtered, evaporated and the residue was purified by flash column chromatography $\left(\mathrm{CHCl}_{3} / \mathrm{MeOH}\right)$ to give the title compound 7 as a thick yellow oil $676 \mathrm{mg}$ (33\%). Calc. for $\mathrm{C}_{15} \mathrm{H}_{29} \mathrm{~N}_{4} \mathrm{O}$ C 64.02, $\mathrm{H}$ 10.39, $\mathrm{N}$ 19.91; found: C 64.15, H 10.35, N 20.05. MS (EI) m/z: $281\left(\mathrm{M}^{+}, 18\right), 251$ (45), 221 (78), 99 (100).

\section{Synthesis of paramagnetic dansyl derivatives 10a, 11a, 12a. General procedure}

To a stirred solution of amines $\mathbf{3}$ or $\mathbf{7}$ or $\mathbf{8}(3.0 \mathrm{mmol})$ and triethylamine $333 \mathrm{mg}$ (3.3 mmol) in $\mathrm{CH}_{2} \mathrm{Cl}_{2}$ (30 mL) dansyl chloride 9 (809 $\mathrm{mg}$, $\left.3.0 \mathrm{mmol}\right)$ dissolved in dry $\mathrm{CH}_{2} \mathrm{Cl}_{2}(10 \mathrm{~mL})$ was added. After stirring the reaction mixture for $4 \mathrm{~h}$ at r.t., the organic phase was washed with brine, separated, dried $\left(\mathrm{MgSO}_{4}\right)$, filtered, evaporated and the residue was purified by flash column chromatography (hexane/EtOAc, $\mathrm{Et}_{2} \mathrm{O} / \mathrm{CHCl}_{3}$ ) to give compounds $\mathbf{1 0 a}$ or $\mathbf{1 1 a}$ or $\mathbf{1 2 a}$ as yellowgreen solids or oils.

N-[4-(1-Oxyl-2,2,5,5-tetramethyl-2,5-dihydro-1 H-pyrrol-3-ylmethyl)piperazin-1-yl]-(5dimethylamino)-1-naphthalenesulfonamide radical (10a). $734 \mathrm{mg}$ (52 \%), mp 143-145 ${ }^{\circ} \mathrm{C}$, calc. for $\mathrm{C}_{25} \mathrm{H}_{35} \mathrm{~N}_{4} \mathrm{O}_{3} \mathrm{~S}$ : C 63.66, H 7.49, N 11.89, S 6.78; found: C 63.75, H 7.65, N 12.00, S 6.95; MS (EI) m/z: 471 (M+, 3), 441 (4), 332 (10), 43 (100). 
$N$-\{2-[4-(1-oxyl-2,2,5,5-tetramethyl-2,5-dihydro-1H-pyrrol-3-ylmethyl)piperazin-1yl]ethyl\}-(5-dimethylamino)-1-naphthalenesulfonamide radical (11a). $894 \mathrm{mg}$ (58 \%), mp 62-65 ${ }^{\circ} \mathrm{C}$, calc. for $\mathrm{C}_{27} \mathrm{H}_{40} \mathrm{~N}_{5} \mathrm{O}_{3} \mathrm{~S}$ : C 63.00, $\mathrm{H}$ 7.84, N 13.61, S 6.22; found: $\mathrm{C} 63.15, \mathrm{H} 7.70, \mathrm{~N}$ 13.85, S 6.35; MS (EI) m/z: $514\left(\mathrm{M}^{+}, 14\right), 499$ (16), 236 (100), 136 (86).

N-(1-oxyl-2,2,5,5-tetramethyl-2,5-dihydro-1H-pyrrol-3-ylmethyl)-5-dimethylamino-1naphtalenesulfonamide radical (12a). $543 \mathrm{mg}$ (45\%), mp 128-129 ${ }^{\circ} \mathrm{C}$, calc. for $\mathrm{C}_{21} \mathrm{H}_{28} \mathrm{O}_{3} \mathrm{~N}_{3} \mathrm{~S}$ : C 62.66, H 7.01, N 10.44, S 7.96; found: C 62.50, H 7.20, N 10.55, S 7.80 MS (EI) m/z: 402 $\left(\mathrm{M}^{+}, 16\right), 372(10), 170$ (42), 110 (100).

Synthesis of diamagnetic dansyl and phthalimidyl derivatives. General procedure

To a solution of nitroxide 10a or 11a or 12a or $14 \mathbf{a}$ or 18 or 19 (2.0 mmol) in glacial acetic acid (10 mL) Fe powder (560 mg, $10.0 \mathrm{mmol}$ ) or (1.12 g, $20.0 \mathrm{mmol}$ in case of $\mathbf{1 8}$ or 19) was added and the mixture was warmed up to $50{ }^{\circ} \mathrm{C}$ until the reaction started and the reaction was stirred for $30 \mathrm{~min}$ at r.t. After diluting water $(30 \mathrm{~mL})$, the solution was decanted from iron residue, and the solution was made alkaline $\left(\mathrm{pH}=9\right.$ ) by adding solid $\mathrm{K}_{2} \mathrm{CO}_{3}$. The reaction mixture was filtered off, the filtrate was extracted with $\mathrm{CHCl}_{3}(3 \mathrm{x} 40 \mathrm{~mL}$ ), and the separated organic phases were combined, dried $\left(\mathrm{MgSO}_{4}\right)$, filtered and evaporated in a vacuum. Flash column chromatography with $\mathrm{CHCl}_{3} / \mathrm{MeOH}$ as eluent afforded the title amines $10 \mathrm{~b}$ or $\mathbf{1 1 b}$ or $\mathbf{1 2 b}$ or $\mathbf{1 4 b}$ or $20 \mathrm{~b}$ or $21 \mathbf{b}$ as yellow-green solids or oils.

$\mathrm{N}$-[4-(2,2,5,5-Tetramethyl-2,5-dihydro-1H-pyrrol-3-ylmethyl)piperazin-1-yl]-(5dimethylamino)-1-naphthalenesulfonamide (10b). $355 \mathrm{mg}$ (39\%), mp 67-72 ${ }^{\circ} \mathrm{C}$, calc. for $\mathrm{C}_{25} \mathrm{H}_{36} \mathrm{~N}_{4} \mathrm{O}_{2} \mathrm{~S}$ : C 65.76, H 7.95, N 12.27, S 7.02; found: C 65.56, H 7.70, N 12.45, S 7.35, MS (EI) m/z: $456\left(\mathrm{M}^{+}, 9\right), 441$ (35), 332 (25), 122 (100).

$N$-\{2-[4-(2,2,5,5-Tetramethyl-2,5-dihydro-1H-pyrrol-3-ylmethyl)piperazin-1-yl]ethyl\}-(5dimethylamino)-1-naphthalenesulfonamide (11b). $320 \mathrm{mg}$ (32\%), mp 205-208, ${ }^{\circ} \mathrm{C}$ calc. for $\mathrm{C}_{27} \mathrm{H}_{41} \mathrm{~N}_{5} \mathrm{O}_{2} \mathrm{~S}$ : C 64.90, H 8.27, N 14.01, S 6.42; found: C 64.70, H 8.40, N 14.20, S 6.25, MS (EI) m/z: 499 (M+12), 396 (10), 236 (76), 136 (100).

N-(2,2,5,5-Tetramethyl-2,5-dihydro-1H-pyrrol-3-ylmethyl)-5-dimethylamino-1naphtalenesulfonamide (12b). $372 \mathrm{mg}$ (48\%), mp 125-126, ${ }^{\circ} \mathrm{C}$, calc. for $\mathrm{C}_{21} \mathrm{H}_{29} \mathrm{O}_{2} \mathrm{~N}_{3} \mathrm{~S}$ : $\mathrm{C} 65.09$, H 7.54, N 10.84, S 8.27; found: C 65.25, H 7.40, N 10.95, S 8.40. MS (EI) m/z: 387 (M+, 3), 372 (19), 122 (58), 110 (100).

$\mathrm{N}$-[(2-Diethylaminoethyl)-N-(2,2,5,5-tetramethylpyrrolidine-3-yl)]-5-dimethylamino-1-

naphthalenesulfonamide (14b). $266 \mathrm{mg}$ (28\%), yellow oil, calc. for $\mathrm{C}_{26} \mathrm{H}_{42} \mathrm{~N}_{4} \mathrm{O}_{2} \mathrm{~S}$ : C 65.79, $\mathrm{H}$ 8.92, N 11.80, S 6.75; found: C 65.65, H 9.05, N 11.70, S 6.90; MS (EI) m/z: $474\left(\mathrm{M}^{+}, 1\right), 170$ (7), 124 (18), 86 (100).

3-Amino- $\mathbf{N}$-(2,2,6,6-tetramethylpiperidine-4-yl)phthalimide (20b). 198 mg (33\%), mp 169$171{ }^{\circ} \mathrm{C}$, calc. for $\mathrm{C}_{17} \mathrm{H}_{23} \mathrm{~N}_{3} \mathrm{O}_{2}$ : C 67.75, $\mathrm{H}$ 7.69, $\mathrm{N}$ 13.94; found $\mathrm{C} 67.90, \mathrm{H}$ 7.85, N 14.10; MS (TSP) m/z: $302(\mathrm{M}+\mathrm{H})^{+}$.

4-Amino- $\mathrm{N}$-(2,2,6,6-tetramethylpiperidine-4-yl)phthalimide (21b). $307 \mathrm{mg}$ (51 \%), mp 241$243{ }^{\circ} \mathrm{C}$, calc. for $\mathrm{C}_{17} \mathrm{H}_{23} \mathrm{~N}_{3} \mathrm{O}_{2}$ : C 67.75, $\mathrm{H}$ 7.69, $\mathrm{N}$ 13.94; found $\mathrm{C} 67.70, \mathrm{H}$ 7.60, N 13.90; MS (TSP) m/z: $302(\mathrm{M}+\mathrm{H})^{+}$. 
Synthesis of $\quad N$-[(2-diethylaminoethyl)- $N$-(1-oxyl-2,2,5,5-tetramethylpyrrolidin-3-yl)]-5dimethylamino-1-naphthalenesulfonamide radical (14a). To a stirred solution of compound 13 (390 mg, $1.0 \mathrm{mmol}$ ) in dry THF (10 mL) NaH (48 mg, $2.0 \mathrm{mmol}$ ) was added in one portion and the suspension was further stirred for $15 \mathrm{~min}$. at $0{ }^{\circ} \mathrm{C}$ under $\mathrm{N}_{2}$. In an Erlenmeyer flask to a stirred solution of 2-(diethylamino)ethyl chloride hydrochloride (860 mg, $5.0 \mathrm{mmol})$ in water $(15 \mathrm{~mL})$ solid $\mathrm{K}_{2} \mathrm{CO}_{3}$ (690 mg, $5.0 \mathrm{mmol}$ ) was added at $0{ }^{\circ} \mathrm{C}$ and the mixture was stirred for $2 \mathrm{~min}$., then extracted with benzene ( $2 \times 10 \mathrm{ml})$. The organic phase was dried $\left(\mathrm{MgSO}_{4}\right)$, filtered, and the solution was added to mixture of the above sulfonamide - Na salt suspension at $0{ }^{\circ} \mathrm{C}$. After adding dry dimethylformamide $(20 \mathrm{~mL})$, the mixture was allowed to warm to room temperature and then refluxed for 3h. After cooling, EtOH (1 mL) was added for destruction of the remaining $\mathrm{NaH}$, then solvents were evaporated off, the residue was dissolved in $\mathrm{CHCl}_{3}(30 \mathrm{~mL})$, washed with brine (20 $\mathrm{mL})$, dried $\left(\mathrm{MgSO}_{4}\right)$, filtered, evaporated. The residue was purified by flash column chromatography to give the title compound as a yellow oil $166 \mathrm{mg}$ (34 \%). Calc. for $\mathrm{C}_{26} \mathrm{H}_{41} \mathrm{~N}_{4} \mathrm{O}_{3} \mathrm{~S}$ : C 63.77, H 8.44, N 11.44, S 6.55; found: 63.80, H 8.55, N 11.60, S 6.45; MS (EI) m/z: 489 (M , 1), 170 (6), 124 (13), 86 (100).

Synthesis of 3-nitro- $N$-(1-oxyl-2,2,6,6-tetramethylpiperidine-4-yl)phthalimide radical (18) and 4-nitro- $N$-(1-oxyl-2,2,6,6-tetramethylpiperidine-4-yl)phthalimide radical (19). In a roundbottomed flask to a solution of amine 17 (855 mg, $5.0 \mathrm{mmol}$ ) in $\mathrm{CHCl}_{3}$ (20 mL), 3-nitrophthalic anhydride 15 (965 mg, $5.0 \mathrm{mmol}$ ) or 4-nitrophthalic anhydride (16) (965 mg, $5.0 \mathrm{mmol}$ ) was added in one portion and after stirring at room temperature for $1 \mathrm{~h}$ the solvents were evaporated off. The gummy residue was suspended in toluene $(50 \mathrm{~mL}), \mathrm{Et}_{3} \mathrm{~N}(1.0 \mathrm{~g}, 10.0 \mathrm{mmol})$ was added and the mixture was heated at $110{ }^{\circ} \mathrm{C}$ under continuous removal of water with Dean-Stark apparatus. After $4 \mathrm{~h}$ further $\mathrm{Et}_{3} \mathrm{~N}$ (500 mg, $5.0 \mathrm{mmol}$ ) was added and the mixture was heated for further $4 \mathrm{~h}$. After cooling, solvents were evaporated off and the residue was dissolved in $\mathrm{CHCl}_{3}(30 \mathrm{~mL})$, washed with brine $(10 \mathrm{~mL})$, dried $\left(\mathrm{MgSO}_{4}\right)$, filtered, evaporated. After purification with flash column chromatography (hexane/EtOAc) we got the title compounds, $18761 \mathrm{mg}$ (44 \%), mp 204-206 ${ }^{\circ} \mathrm{C}$. Calc. for $\mathrm{C}_{17} \mathrm{H}_{20} \mathrm{~N}_{3} \mathrm{O}_{5}$ : C 58.95, $\mathrm{H}$ 5.82, N 12.13; found: C 58.80, H $6.00 \mathrm{~N} \mathrm{12.15;} \mathrm{MS} \mathrm{(EI)} \mathrm{m/z:}$ $346\left(\mathrm{M}^{+}, 6\right), 332$ (18), 316 (8), 41 (100), or $19519 \mathrm{mg}$ (30\%), mp 242-244 ${ }^{\circ} \mathrm{C}$. Calc. for $\mathrm{C}_{17} \mathrm{H}_{20} \mathrm{~N}_{3} \mathrm{O}_{5}$ : C 58.95, H 5.82, N 12.13; found: C 58.70, H 6.10 N 12.30; MS (EI) m/z: 346 (M , 7), 332 (22), 316 (12), 41 (100) as brown-red solids.

Synthesis of 3-amino- $N$-(1-oxyl-2,2,6,6-tetramethylpiperidine-4-yl)phthalimide radical (20a) and 4-amino- $N$-(1-oxyl-2,2,6,6-tetramethylpiperidine-4-yl) phthalimide radical (21a). To a stirred solution of compound 18 or 19 (692 mg, $2.0 \mathrm{mmol}$ ) and $\mathrm{HCO}_{2} \mathrm{NH}_{4}$ (756 mg, $12.0 \mathrm{mmol}$ ) in $\mathrm{MeOH}(30 \mathrm{~mL}) \mathrm{Pd} / \mathrm{C}$ (100 mg, 10\%) was added in one portion at $40{ }^{\circ} \mathrm{C}$ and the mixture was further stirred for $2 \mathrm{~h}$ at this temperature under $\mathrm{N}_{2}$. The mixture was filtered through Celite, the filter cake was washed with hot $\mathrm{MeOH}(2 \times 10 \mathrm{~mL})$ and the combined filtrates were evaporated to dryness. The residue was dissolved in $\mathrm{CHCl}_{3}(40 \mathrm{~mL})$, washed with brine, dried $\left(\mathrm{MgSO}_{4}\right)$, then $\mathrm{PbO}_{2}$ (239 mg, $1.0 \mathrm{mmol}$ ) was added and $\mathrm{O}_{2}$ was bubbled through mixture for $15 \mathrm{~min}$. After filtration the mixture was evaporated and after flash column chromatography we got the title compounds as yellow solids 20a $176 \mathrm{mg}$ (28\%), mp 227-232 ${ }^{\circ} \mathrm{C}$, calc. for $\mathrm{C}_{17} \mathrm{H}_{22} \mathrm{~N}_{3} \mathrm{O}_{3}$ : C 64.54, $\mathrm{H}$ 7.01, N 13.28; found C 64.70, H 7.00 N 13.10. MS (EI) m/z: 316 (M+24), 302 (52), 175 (90), 
124 (100) or compound 21a $227 \mathrm{mg}$ (36\%), mp 178-180 ${ }^{\circ} \mathrm{C}$, calc. for $\mathrm{C}_{17} \mathrm{H}_{22} \mathrm{~N}_{3} \mathrm{O}_{3}$ : C 64.54, $\mathrm{H}$ 7.01, N 13.28; found C 64.40, H 7.10, N 13.15. MS (EI) m/z: 316 (M+15), 302 (53), 175 (72), 124 (100).

\section{Acknowledgements}

This work was supported by grants from the Hungarian National Research Foundation (OTKA T 034307). The authors wish to express thanks to M. Balog for technical assistance and M. Szabó (ICN Hungary Ltd.) for mass spectral measurements.

\section{References and Notes}

1. Kálai, T.; Hideg, É.; Vass, I.; Hideg, K. Free Rad. Biol. \& Med. 1998, 24, 649.

2. Hideg, É.; Kálai, T.; Hideg, K.; Vass, I., Biochemistry 1998, 37, 11405.

3. Kieber, D. J.; Blough, N. V. Free Rad. Res. Commun. 1990, 10, 109.

4. Li, B.; Gutierrez, P. L.; Blough, N. V. Anal. Chem. 1997, 69, 4295.

5. Flicker, T. M.; Green, S. Anal. Chem. 1998, 70, 2008.

6. (a) Bystryak, I. M.; Likhtenshtein, G. I.; Kotelnikov, A. I.; Hankovszky, H. O.; Hideg, K. Russian Journal of Phys. Chem. 1986, 60, 1679. (b) Vogel, V. R.; Rubtsova, E. T.; Likhtenshtein, G. I.; Hideg, K. J. Photochem. Photobiol. A: Chem. 1994, 83, 229. (c) Lozinsky, E.; Shames, A. I.; Likhtenshtein, G. I. Rec. Res. Devel. Photochem. \& Photobiol. 2001, 5, 41.

7. Green, S. A.; Simpson, D. J.; Zhou, G.; Ho, P. S.; Blough, N. V. J. Am. Chem. Soc. 1990, 112, 7337.

8. Herbelin, S. E.; Blough, N. V. J. Phys. Chem. B. 1998, 102, 8170.

9. Twomey, P.; Taira, J.; DeGraff, W.; Mitchell, J. B.; Russo, A.; Krishna, M. C.; Hankovszky, H. O.; Frank, L.; Hideg, K. Free Rad. Biol. \& Med. 1997, 22, 909.

10. Hideg, É.; Ogawa, K; Kálai, T.; Hideg, K. Physiol. Plant. 2001, 112, 10.

11. Hankovszky, H. O.; Lex, L.; Hideg, K. Synthesis 1980, 914.

12. Hideg, K.; Hankovszky, H. O. Acta Chim. Acad. Sci. Hung. 1963, 39, 391.

13. Akiyama, M.; Katoh, A.; Ogawa, T. J. Chem. Soc., Perkin 2, 1989, 1213.

14. Hankovszky, H. O.; Hideg, K.; Lex, L. Synthesis 1981, 147.

15. Sár, P. C.; Kálai, T.; Bárácz, M. N.; Jerkovich, Gy. Hideg, K. Synth. Commun. 1995, 25, 2929.

16. (a) Lakowicz, J. R. In Principles of Fluoresence Spectroscopy; Kluwer Academic/ Plenum Publishers, 1999; pp 368-394. (b) Turro, N. J. Modern Molecular Photochemistry; University Science Books, 1991; pp 296-361.

17. Stryer, L.; Griffith, H. O. P. Natl. Acad. Sci., USA 1965, 54, 1785.

18. Weisz, K.; Lengeler, D. Tetrahedron Lett. 2001, 42, 1479.

19. Ram, S.; Ehrenkaufer, R. E. Synthesis 1988, 91. 